Boston University School of Law

Scholarly Commons at Boston University School of Law

Faculty Scholarship

1996

Cowboys, Camels, and the First Amendment: The FDA's

Restrictions on Tobacco Advertising

George J. Annas

Follow this and additional works at: https://scholarship.law.bu.edu/faculty_scholarship

Part of the First Amendment Commons, and the Health Law and Policy Commons 
Legal Issues in Medicine

\section{Cowboys, Camels, and the First Amendment - The FDA's RESTRICTIONS ON TOBACCO Advertising}

\author{
George J. AnnAS, J.D., M.P.H.
}

\section{$\mathrm{T}$} HE Marlboro Man and Joe Camel have become public health enemies number one and two, and removing their familiar faces from the gaze of young people has become a goal of President Bill Clinton and his health care officials. ${ }^{1}$ The strategy of limiting the exposure of children to tobacco advertisements is based on the fact that almost all regular smokers begin smoking in their teens. This approach is politically possible because most Americans believe that tobacco companies should be prohibited from targeting children in their advertising.

Shortly before the 1996 Democratic National Convention, the President announced that he had approved regulations drafted by the Food and Drug Administration (FDA) to restrict the advertising of tobacco products to children. At the convention, Vice-President Al Gore told the delegates, "Until I draw my last breath, I will pour my heart and soul into the cause of protecting our children from the dangers of smoking." 2 In a press conference at the White House immediately following the announcement, Health and Human Services Secretary Donna Shalala said, "This is the most important public health initiative in a generation. It ranks with everything from polio to penicillin. I mean, this is huge in terms of its impact." 3

No one doubts that a substantial reduction in the number of teenage smokers would mean a substantial reduction in the number of adult smokers when these teenagers grow up, and this reduction would have a major effect on health and longevity. Since almost 50 million Americans smoke, the result of reducing the number of young smokers substantially would indeed be "huge in terms of its impact." The real question is not whether the goal is appropriate but whether the means proposed to reach it are likely to be effective. In this regard, the FDA regulations may be unsuccessful for either of two related reasons: the implementation of the regulations may not reduce the number of teenagers who start smoking, or some of the regulations may be found to violate the First Amendment.

\section{THE REGULATIONS}

The FDA's new regulations are designed to reduce the demand for tobacco products among teenagers, which is consistent with the goal of the Healthy People 2000 program to reduce by half (to 15 percent) the proportion of children who use tobacco products. ${ }^{1,4}$ The FDA has somewhat modified the time line: the goal of its regulations is to cut underage smoking by half in seven years. Although the FDA has never before asserted jurisdiction over cigarettes or smokeless tobacco, the agency bases its claim to jurisdiction over these two types of products on its authority to regulate medical devices, defining cigarettes as a "drug-delivery device." Of course, this means that the FDA also defines nicotine as a drug. The regulations apply to sellers, distributors, and manufacturers of tobacco products. Sellers may not sell cigarettes or smokeless tobacco to anyone under the age of 18 years and must verify the age of purchasers under 26 by checking a form of identification bearing a photograph, in a "direct, face-to-face exchange." Exceptions are sales through mail orders and vending machines located in facilities that persons under the age of 18 years are not permitted to enter at any time. The distribution of free samples is also outlawed, as is the sale of cigarettes in packs of fewer than 20 (so-called kiddie packs). All cigarettes and smokeless tobacco products must bear the following statement: "Nicotinedelivery devices for persons 18 or older." 1

The most controversial portions of the regulations deal with advertising. One section outlaws all outdoor advertising within 1000 feet of public playgrounds and elementary and secondary schools. Advertising is restricted to "black text on a white background." This restriction applies to all billboards but not to "adult publications." Such publications are defined by the regulations as "any newspaper, magazine, periodical or other publication . . . whose readers younger than 18 years of age constitute 15 percent or less of the total readership as measured by competent and reliable survey evidence; and that is read by fewer than 2 million persons younger than 18 years of age." 1 Tobacco manufacturers and distributors are prohibited from marketing any item (other than cigarettes or smokeless tobacco) that bears a brand name used for cigarettes or smokeless tobacco and are prohibited from offering any gift to a person purchasing cigarettes or smokeless tobacco products. ${ }^{1}$ Finally, "no manufacturer, distributor, or retailer may sponsor or cause to be sponsored any athletic, musical, artistic, or other social or cultural event, or any entry or team in any event, [under] the brand name [of a tobacco product] (alone or in conjunction with any other words)." Such events may, however, be sponsored under the name of the corporation that manufac- 
tures the tobacco product, provided that the corporate name existed before 1995 and does not include a brand name.

\section{THE LEGAL CHALLENGE}

Tobacco companies have already filed suit to enjoin enforcement of the regulations. According to FDA Commissioner David Kessler, the FDA decided to assert its jurisdiction over cigarettes when the scientific community determined that the nicotine in tobacco products is addictive, and when the FDA concluded that the tobacco companies were probably manipulating the levels of nicotine to maintain their market of addicted users. ${ }^{5}$ Under the legislation that gives the FDA its authority, a drug is any product "intended to affect the structure or any function of the body." The FDA contends that cigarettes and smokeless tobacco can be properly viewed as devices for delivering the drug nicotine, because they meet all three independent criteria for determining whether a product is a drug-delivery device: "a reasonable manufacturer would foresee that the product will be used for pharmacologic purposes [or] that consumers actually use it for such purposes [or] the manufacturer expects or designs the product to be used in such a manner." 5

The primary argument of the tobacco companies is that Congress has consistently refused to give the FDA jurisdiction over tobacco products, and until now, the FDA itself has consistently said that it has no jurisdiction over such products. Moreover, the companies assert that if the FDA had jurisdiction over cigarettes as a drug or drug-delivery device, the FDA would have to ban them as not being "safe," which Congress has repeatedly refused to do or permit.

The second argument used by the tobacco companies, which is the focus of this article, is that the regulations violate the First Amendment of the U.S. Constitution by restricting the right to free speech in advertising. Congress could vote to give the FDA authority over tobacco but could not, of course, change the First Amendment.

\section{THE FIRST AMENDMENT AND ADVERTISING}

The basic test used to determine whether the government can ban advertising is set out in the Supreme Court's 1980 opinion in Central Hudson Gas of Electric Corporation v. Public Service Commission of New York. ${ }^{6}$ This case involved a regulation that prohibited electric utilities from advertising to promote the use of electricity. The court adopted a four-part test to determine whether this regulation was constitutional: (1) to be protected by the First Amendment, the advertising must concern a lawful activity and not be misleading, (2) for the ban to be valid, the state's interest in banning the advertising must be "substantial," (3) the ban must "directly advance" the state's interest, and (4) it must be no more extensive than necessary to further the state's interest. ${ }^{6}$ In Central Hudson, the Supreme Court concluded that although the state had a substantial interest in energy conservation that was advanced by the ban on advertising, the ban nonetheless failed the fourth part of the test. The ban failed that part because it was overly broad, prohibiting the promotion of potentially energy-saving electric services, and there was no proof that a more limited restriction of advertising could not have achieved the same goal. The court suggested, as an example, that a narrower regulation could have required "that the advertisements include information about the relative efficiency and expense of the offered services."

In 1986, in Posadas de Puerto Rico Associates v. Tourism Company of Puerto Rico, the Supreme Court upheld a ban on advertisements for casino gambling in Puerto Rico. ${ }^{7}$ The court held that this ban met the four parts of the test in Central Hudson. Adding that the government could ban advertising for any activity that it could outlaw, the court said it would be "a strange constitutional doctrine which would concede to the legislature the authority to totally ban a product or activity, but deny to the legislature the authority to forbid the stimulation of demand for the product or activity through advertising."7 The court gave a number of other examples of "vice" products or activities, including cigarettes, alcoholic beverages, and prostitution, which struck many in the public health community as warranting restricted advertising. Of course, fashions change, and many states now promote and advertise gambling, in the form of lotteries and casinos, as good for the financial health of the government. Nonetheless, in the wake of the May 1996 decision in $44 \mathrm{Liq}$ uormart $\mathrm{v}$. Rhode Island, ${ }^{8}$ the most recent and comprehensive case involving free speech in advertising, it is unlikely that Posadas will continue to be invoked. Moreover, the four-part test in Central Hudson will be more strictly applied in the future.

\section{THE 44 LIQUORMART CASE}

In 44 Liquormart v. Rhode Island, a liquor retailer challenged the Rhode Island laws that banned all advertisements of retail liquor prices, except at the place of sale, and prohibited the media from publishing any such advertisements, even in other states. 44 Liquormart had published an advertisement identifying various brands of liquor that included the word "wow" in large letters next to pictures of vodka and rum bottles. An enforcement action against the company resulted in a $\$ 400$ fine. After paying the fine, 44 Liquormart appealed, seeking a declaratory judgment that the two statutes and the implementing regulations promulgated under them violated the First Amendment. 
The U.S. District Court declared the ban on price advertising unconstitutional because it did not "directly advance" the state's interest in reducing alcohol consumption and was "more extensive than necessary to serve that interest." 9 The Court of Appeals reversed the decision, finding "inherent merit" in the state's argument that competitive price advertising would lower prices and that lower prices would induce more sales. ${ }^{10}$ In reviewing these decisions, the Supreme Court unanimously found that the state laws violated the First Amendment, but no rationale for this opinion gained more than four votes. Justice John Paul Stevens (who wrote the principal opinion) began his discussion by quoting from an earlier case involving advertisements of prices for prescription drugs:

Advertising, however tasteless and excessive it sometimes may seem, is nonetheless dissemination of information as to who is producing and selling what product, for what reason, and at what price. So long as we preserve a predominantly free enterprise economy, the allocation of our resources in large measure will be made through numerous private economic decisions. It is a matter of public interest that those decisions, in the aggregate, be intelligent and well informed. To this end, the free flow of commercial information is indispensable. ${ }^{8}$

Justice Stevens went on to note that "complete speech bans, unlike content-neutral restrictions on the time, place, or manner of expression . . . are particularly dangerous because they all but foreclose alternative means of disseminating certain information." Bans unrelated to consumer protection, Stevens noted further, should be treated with special skepticism when they "seek to keep people in the dark for what the government perceives to be their own good." Stevens moved on to apply Central Hudson's four-point test. He concluded that "there is no question that Rhode Island's price advertising ban constitutes a blanket prohibition against truthful, nonmisleading speech about a lawful product." Stevens also agreed that the state has a substantial interest in "promoting temperance."

But can the state meet part three of the test, by showing that the ban is effective in advancing this interest? Four justices defined the third part of the test as requiring the state to "bear the burden of showing not merely that its regulation will advance its interest but also that it will do so 'to a material degree." " This requirement is necessary because of the "drastic nature" of the state's ban: "the wholesale suppression of truthful, nonmisleading information." Justice Stevens concluded that Rhode Island did not meet this requirement and could not do so without "any findings of fact" or other evidence. The common-sense notion that prohibitions against price advertising will lead to higher prices and thus lower consumption (an assumption made in Central Hudson) was found insufficient to support a finding that the restriction of advertising would "significantly reduce market-wide consumption." "Speculation or conjecture" does not suffice. ${ }^{9}$

As for the fourth part of the test, Justice Stevens concluded that the ban also failed because Rhode Island did not show that alternative forms of regulation that do not limit speech, such as limiting per capita purchases or using educational campaigns that address the problem of excessive drinking, could not be equally or more effective in reducing consumption. All nine members of the Supreme Court agreed with this conclusion. Finally, Justice Stevens (again on behalf of four justices) argued that in $\mathrm{Po}^{-}$ sadas the court had wrongly concluded that since the state could ban a product or activity, it could ban advertising about it. He argued that the First Amendment was much stronger than that decision implied, noting "We think it quite clear that banning speech may sometimes prove far more intrusive than banning conduct," and thus it is not true that "the power to prohibit an activity is necessarily 'greater' than the power to suppress speech about it. . . . The text of the First Amendment makes clear that the Constitution presumes that attempts to regulate speech are more dangerous than attempts to regulate conduct." the idea that "vice" activities have less protection from the First Amendment than other commercial activities, noting that the distinction would be "difficult, if not impossible, to define."

\section{FREE SPEECH AND THE FDA REGULATIONS}

Selling cigarettes and smokeless tobacco to persons under the age of 18 years is illegal in all states, so advertising to this age group is not protected by the First Amendment. Nor does outlawing vending machines that children have access to pose a problem with respect to the First Amendment. Because the FDA regulations are intended to apply only to children and do not foreclose alternative sources of information, it is impossible to predict with certainty how the Supreme Court will respond to a First Amendment challenge (assuming the court finds that the FDA has authority in this area). Nonetheless, the areas of primary concern can be identified.

Bans will be subject to a higher standard of review than restrictions. Forms of advertising that are banned include the distribution of products (other than cigarettes and smokeless tobacco) with the tobacco brand name or insignia on them, the placement of billboards within 1000 feet of playgrounds and elementary and secondary schools, and the use of brand names for sporting and cultural events. If the court adopts the strict version of the third part of the test in Central Hudson, the FDA will have to present evidence that these bans will reduce underage smoking to a material degree. Moreover, to meet 
the fourth part of the test, which the court unanimously found was not met in 44 Liquormart, the FDA must also show that no other, less restrictive method, such as antismoking advertising or better enforcement of existing laws, would work as well. This will be difficult, especially since the FDA commissioner has already said he believes that antismoking advertising is effective in helping young people understand the risks of smoking and that, after the publication of its rules, the agency plans "to notify the major cigarette and smokeless-tobacco companies that it will begin discussing a requirement that they fund an education program in the mass media." ${ }^{5}$ The court could decide that a nonspeech ban should have been tried first.

Restrictions on advertising may be easier to uphold, but even they are not obviously permissible. The tobacco companies spend $\$ 6$ billion a year in advertising and promotion, about $\$ 700$ million of which is spent on magazine advertisements. ${ }^{11}$ The core antiadvertising regulation requires that advertisements on all billboards and in publications that do not qualify as adult publications be limited to black text on a white background. ${ }^{1}$ This is a restriction (not a ban) and does not prohibit the inclusion of factual information (such as the price of liquor, which was at issue in 44 Liquormart). The rationale for these rules is that images in bright colors, of which Joe Camel is the primary example, entice children to start smoking or continue to smoke. Since no objective information is being banned or restricted, the court may find that such a restriction need meet only a common-sense test. ${ }^{12}$ If, however, the court takes a more sophisticated view of advertising - which is largely focused on image rather than text - it may well hold that the same rules apply and that therefore the burden of proof is on the FDA to demonstrate that such a restriction would reduce underage smoking to a material degree. No study has yet been able to show evidence of this effect. Consistent with the view that "pop art" should be protected at least as much as text is the view that advertising images are art forms designed to elicit certain responses and as such are entitled to at least as much protection from the First Amendment as objective information.

Drastic restrictions on advertising may also be ineffective or even counterproductive. In Britain, for example, where both Joe Camel and the Marlboro Man are outlawed and tobacco advertisers are prohibited from using anything that suggests health, fresh air, or beauty, creative advertisers have found other ways to promote tobacco products. Advertisements for Silk Cut cigarettes feature various images of silk being cut (e.g., scissors dancing a cancan in purple silk skirts and a rhinoceros whose horn pierces a purple silk cap), and Marlboro advertisements portray bleak and forbidding western U.S. land- scapes with the words, "Welcome to Marlboro Country." It has been suggested that by using such surreal images, tobacco advertisers may be appealing to fantasies of death and sexual violence that have a powerful (if unconscious) appeal to consumers. ${ }^{13}$ Such imagery may actually have greater appeal for teenagers than Joe Camel. U.S. advertising agencies have already experimented with black-and-white, textonly advertisements. One agency proposed that the required phrase, "a nicotine-delivery device," can be used in conjunction with the phrase ".cyber cigarettes" on one line, under the phrase (in larger type) "pleasure.com" and a sideways smiling face, formed by a colon, a hyphen, and a closed parenthesis [:-)], to suggest that nicotine is a pleasure of the cyberspace age. ${ }^{14}$

The FDA knows it has a First Amendment problem here. In its comments accompanying the regulations, the agency argues that it is not required to "conclusively prove by rigorous empirical studies that advertising causes initial consumption of cigarettes and smokeless tobacco." In fact, the FDA says it is impossible to prove this. Instead, the agency argues it need only demonstrate that there is "more than adequate evidence" that "tobacco advertising has an effect on young people's tobacco use behavior if it affects initiation, maintenance, or attempts at quitting." The FDA's position follows from the conclusion of the Institute of Medicine:

Portraying a deadly addiction as a healthful and sensual experience tugs against the nation's efforts to promote a tobacco-free norm and to discourage tobacco use by children and youths. This warrants legislation restricting the features of advertising and promotion that make tobacco use attractive to youths. The question is not, "Are advertising and promotion the causes of youth initiation?" but rather, "Does the preponderance of evidence suggest that features of advertising and promotion tend to encourage youths to smoke?" The answer is yes and this is a sufficient basis for action, even in the absence of a precise and definitive causal chain. ${ }^{13}$

The Surgeon General has reached a similar conclusion:

Cigarette advertising uses images rather than information to portray the attractiveness and function of smoking. Human models and cartoon characters in cigarette advertising convey independence, healthfulness, adventure-seeking, and youthful activities - themes correlated with psychosocial factors that appeal to young people. ${ }^{15}$

The Supreme Court may make an exception for tobacco advertisements because of the clear health hazards and the use of restrictions instead of bans, but the extent of the restrictions will have to be justified. In this regard, the 15 percent young-readership rule for publications is difficult to justify as either not arbitrary or not more restrictive than necessary. The FDA admits, for example, that its rule would require the following magazines to use black- 
and-white, text-only advertisements: Sports Illustrated (18 percent of its readers are under the age of 18), Car and Driver (18 percent), Motor Trend (22 percent), Road and Track (21 percent), Rolling Stone (18 percent), Vogue (18 percent), Mademoiselle (20 percent), and Glamour (17 percent). ${ }^{1}$ The FDA seems particularly offended by "a cardboard Joe Camel pop-out" holding concert tickets in the center of Rolling Stone. ${ }^{5}$ (Some Americans might wish to censor the photograph of a naked Brooke Shields on the cover of the October 1996 issue as well, although that image is clearly protected by the First Amendment.) A 25 percent rule, for example, would exempt all these magazines.

The FDA justifies the 15 percent rule by arguing that young people between the ages of 5 and 17 years constitute approximately 15 percent of the U.S. population and that "if the percentage of young readers of a publication is greater than the percentage of young people in the general population, the publication can be viewed as having particular appeal to young readers." A similar argument can, of course, be made with regard to sporting and cultural events - some of which may have very few young people in attendance. ${ }^{15}$ On the other hand, the billboard restrictions seem to have a more solid justification.

Tobacco companies profit handsomely by selling products that cause serious health problems and contribute to the deaths of millions of Americans. There is also little doubt that nicotine is physically addictive and that it is in the interest of tobacco companies to get children addicted early, since very few people take up smoking after the age of 18 years. The FDA admits, however, that it cannot prove that cigarette advertising causes children to begin to smoke, and the agency has not tried alternative measures, such as strictly enforcing current laws that prohibit sales to minors and engaging in a broad-based educational campaign against smoking, to reduce the number of children who smoke. Until the FDA either proves that cigarette advertising causes children to start smoking or uses methods of discouraging smoking that stay clear of the First Amendment, bans and restrictions on advertising will raise enough problems with the First Amendment to ensure that they will be tied up in court for years. This does not mean, however, that no immediate legal actions can be taken against tobacco companies. In a future article, I will discuss current trends in litigation against these companies and assess the likely impact of antismoking lawsuits on the tobacco companies.

\section{REFERENCES}

1. Food and Drug Administration, Department of Health and Human Services. Regulations restricting the sale and distribution of cigarettes and smokeless tobacco to protect children and adolescents. Fed Regist 1996; 6l(168):44, 396-618.

2. Gore speech: "America is strong. Bill Clinton's leadership paying off." New York Times. August 29, 1996:B12.

3. Press Briefing by Secretary of HHS Donna Shalala, FDA Commissioner David Kessler, and Assistant Secretary Phil Lee. White House, Office of Press Secretary, August 23, 1996.

4. Trends in smoking initiation among adolescents and young adults United States, 1980-1989. MMWR Morb Mortal Wkly Rep 1995;44:5215

5. Kessler DA, Witt AM, Barnett PS, et al. The Food and Drug Administration's regulation of tobacco products. N Engl J Med 1996;335:988-94 6. Central Hudson Gas \& Electric Corp. v. Public Service Commission of New York, 447 U.S. 557 (1980).

7. Posadas de Puerto Rico Associates v. Tourism Company of Puerto Rico, 478 U.S. 328 (1986).

8. 44 Liquormart, Inc. v. Rhode Island, 116 S. Ct. 1495 (1996)

9. 44 Liquor Mart, Inc. v. Racine, 829 F. Supp. 543 (R.I. 1993)

10. 44 Liquor Mart, Inc. v. Rhode Island, 39 F. 3d 5 (lst Cir. 1994).

11. Committee on Preventing Nicotine Addiction in Children and Youths, Institute of Medicine. Growing up tobacco free: preventing nicotine addiction in children and youths. Washington, D.C.: National Academy Press, 1994:131.

12. Glantz L. Regulating tobacco advertising: the FDA regulations and the First Amendment. Am J Public Health (in press).

13. Parker-Pope T. Tough tobacco-ad rules light creative fires. Wall Street Journal. October 9, 1996:B1.

14. Brownlee L. How agency teams might cope with U.S. ad restraints. Wall Street Journal. October 9, 1996:B1.

15. Department of Health and Human Services. Preventing tobacco use among young people: a report of the Surgeon General. Washington, D.C.: Government Printing Office, 1994:195.

(C)1996, Massachusetts Medical Society. 